\title{
RESEARCH
}

\section{Aortic effects of thyroid hormone in male mice}

\author{
Sogol Gachkar1, Sebastian Nock1, Cathleen Geissler2, Rebecca Oelkrug1, Kornelia Johann'1, Julia Resch1, \\ Awahan Rahman33, Anders Arner ${ }^{4}$, Henriette Kirchner ${ }^{2}$ and Jens Mittag'
}

${ }^{1}$ Molecular Endocrinology, Medical Department I, University of Lübeck, Lübeck, Germany

2Epigenetics \& Metabolism, Medical Department I, University of Lübeck, Lübeck, Germany

3Department for Comparative Medicine, Karolinska Institutet, Stockholm, Sweden

${ }^{4}$ Department of Cardiothoracic Surgery, Clinical Sciences Lund, Lund University, Lund, Sweden

Correspondence should be addressed to J Mittag: jens.mittag@uni-luebeck.de

\begin{abstract}
It is well established that thyroid hormones are required for cardiovascular functions; however, the molecular mechanisms remain incompletely understood, especially the individual contributions of genomic and non-genomic signalling pathways. In this study, we dissected how thyroid hormones modulate aortic contractility. To test the immediate effects of thyroid hormones on vasocontractility, we used a wire myograph to record the contractile response of dissected mouse aortas to the adrenergic agonist phenylephrine in the presence of different doses of T3 (3,3',5-triiodothyronine). Interestingly, we observed reduced vasoconstriction under low and high T3 concentrations, indicating an inversed U-shaped curve with maximal constrictive capacity at euthyroid conditions. We then tested for possible genomic actions of thyroid hormones on vasocontractility by treating mice for 4 days with $1 \mathrm{mg} / \mathrm{L}$ thyroxine in drinking water. The study revealed that in contrast to the non-genomic actions the aortas of these animals were hyperresponsive to the contractile stimulus, an effect not observed in endogenously hyperthyroid TR $\beta$ knockout mice. To identify targets of genomic thyroid hormone action, we analysed aortic gene expression by microarray, revealing several altered genes including the wellknown thyroid hormone target gene hairless. Taken together, the findings demonstrate that thyroid hormones regulate aortic tone through genomic and non-genomic actions, although genomic actions seem to prevail in vivo. Moreover, we identified several novel thyroid hormone target genes that could provide a better understanding of the molecular changes occurring in the hyperthyroid aorta.
\end{abstract}
Key Words
- thyroid hormone receptor $\beta$
- aorta
- gene expression
- hyperthyroidism
- hypothyroidism
- vasoconstriction

\section{Introduction}

Thyroid hormone (TH) is an important regulator of cardiovascular functions. This becomes evident in patients with hyperthyroidism presenting with tachycardia and cardiac hypertrophy, while bradycardia is a characteristic of hypothyroid individuals (Klein \& Ojamaa 2001). In addition to its direct effects on the heart (Dillmann 2010), $\mathrm{TH}$ also affects the vascular system. It was for instance reported that hyper- as well as hypothyroidism are associated with increased arterial stiffness in patients, with negative effects on vascular ageing and atherosclerosis (Obuobie et al. 2002, Delitala et al. 2015, Ittermann et al. 2016). Likewise, increased aortic stiffness was also observed in animal models of hyperthyroidism (Moulakakis et al. 2007) or reduced TH signalling (Warner et al. 2013).

The majority of TH's effects are mediated by nuclear $\mathrm{TH}$ receptors. Two different genes code for $\mathrm{TH}$ receptor 
$\alpha(\operatorname{TR} \alpha)$ and $\beta$ (TR $\beta)$, which have a distinct and partially overlapping expression pattern throughout the body (Yen 2001). These receptors bind to TH response elements in the promotor region of target genes and dependent on hormone availability either recruit corepressors or coactivators to regulate gene expression (Yen 2001). In addition to these genomic effects, several studies have also reported so-called non-genomic effects, which sometimes also require TH receptors (Flamant et al. 2017). The precise mechanisms often depend on the cellular system, as some have reported that 3,3',5-triiodothyronine (T3) activates the PI3 kinase pathway through cytosolic TR $\beta$ (Cao et al. 2005), while others showed an action of T3 on a plasma membrane-bound TR $\alpha$, which in turn activates the ERK pathway (Kalyanaraman et al. 2014). There is also some support for the relevance of these non-genomic pathways in vivo, indicating an involvement of cytosolic TR $\beta$ and PI3 kinase signalling in mouse hippocampal synpase maturation (Martin et al. 2014) or non-genomic TR 1 action in the regulation of cardiac functions (Hönes et al. 2017). However, the individual contributions of genomic and non-genomic effects for specific well-known effects of $\mathrm{TH}$ often remain enigmatic, and cannot be generalized for all cellular systems.

Here, we aim to dissect the genomic and non-genomic effects of TH on the aorta, both on the functional level using myography to record the aortic responses to a contractile stimulus as well as on the molecular level studying cytosolic and genomic signalling pathways.

\section{Materials and methods}

\section{Experimental animals and treatment}

For all animal studies, C57BL/6 wild-type male mice (Charles River, Germany) at the age of 8-12 weeks were housed at ambient temperature $\left(23^{\circ} \mathrm{C}\right)$ on a 12 -h light/12-h dark cycle. For the T4 treatment, the two different animal groups had ad libitum access to water, which contained either $1 \mathrm{mg} / \mathrm{L}$ T4 (Sigma - T2376, dissolved in $0.1 \mathrm{M} \mathrm{NaOH})$ and $0.1 \%(\mathrm{~m} / \mathrm{v})$ bovine serum albumin (BSA) for the treated group, or only $0.1 \%(\mathrm{~m} / \mathrm{v})$ BSA for the control group. After four days of treatment the animals were sacrificed and their abdominal aortas were dissected for RNA isolation or myography. TR $\beta$ knockout mice are from 129sv mice as described previously (Forrest et al. 1996a), which have been backcrossed for at least six generations to C57BL/6 and were bred at the GTH animal facility of the University of Lübeck. All animal procedures were approved by the Ministerium für Energiewende,
Landwirtschaft, Umwelt und ländliche Räume (MELUND Schleswig Holstein, Germany).

\section{Total T3 and total T4 ELISA}

Serum concentrations of total $\mathrm{T}_{3}$ (tT3) and total $\mathrm{T}_{4}$ (tT4) were determined with commercially available ELISA Kits (total Thyroxine ELISA, EIA-1781, DRG Instruments $\mathrm{GmbH}$, Marburg, Germany, and total T3 ELISA, DNOV053, NovaTec Immundiagnostica GmbH, Dietzenbach, Germany) and experiments were performed in accordance with manufacturer's instructions.

\section{Myography}

The contractility of dissected aortas was measured using a wire myograph device (520A-DMT; AD Instruments, Oxford, UK) as described previously (Warner et al. 2013, Gachkar et al. 2017). Briefly, short pieces of abdominal aortas $(2 \mathrm{~mm})$ were dissected carefully in a Petri dish containing Krebs-Ringer buffer (KRB; $123 \mathrm{mM} \mathrm{NaCl}$, $4.7 \mathrm{mM} \mathrm{KCL}, 1.2 \mathrm{mM} \mathrm{KH} \mathrm{PO}_{4}, 1.2 \mathrm{mM} \mathrm{MgCl}_{2}, 20 \mathrm{mM}$ $\mathrm{NaHCO}_{3}, \quad 2.5 \mathrm{mM} \mathrm{CaCl} 2$ and $5.5 \mathrm{mM}$ glucose). After removing the adventitia from the vessel segments, two wires $(2 \mathrm{~cm}$ long and $40 \mu \mathrm{m}$ in diameter) were threaded through each segment. The wires with the vessel segments were mounted into the myograph chamber, which was filled with $10 \mathrm{~mL}$ of KRB. During the whole experiment, the chamber was maintained at $37^{\circ} \mathrm{C}$ and bubbled with carbogen gas $\left(95 \% \mathrm{O}_{2} / 5 \% \mathrm{CO}_{2}\right)$, in order to maintain physiological conditions. Aortas were acclimated for about $1 \mathrm{~h}$. By increasing the diameter and recording the corresponding active contraction, the optimal diameter for active tension was determined. T3 was dissolved in DMSO and diluted in KRB $(0.01 \%$ final concentration of DMSO in the chamber), and aortas were incubated in the chamber for 5 min with different doses of T3 (either 1, 10 or 100 nM; Sigma - T72877). Subsequently, a dose-response curve with phenylephrine (PE) was performed. Increasing doses of PE $\left(10^{-8}\right.$ to $\left.10^{-2} \mathrm{M}\right)$ were added in 3 min intervals into the chamber. The induced forces were recorded using LabChart 8.1 software and normalized to the previously recorded $\mathrm{KCl}$ stimulation force at the optimal diameter using LabChart 8.1 software. For the analysis, the induced forces were plotted against the corresponding doses of PE in logarithmic scale, and a non-linear fit using the least square method with three variables (top, bottom, $\mathrm{EC}_{50}$ ) was used. To account for a possible variability in the response to potassium after different numbers of prestimulations for optimal tension determination, 
only vessels that were run in the same recording session were compared using GraphPad Prism 5 software.

\section{Western blot}

Western blot analysis was performed as described previously (Gachkar et al. 2017). All used antibodies are listed in Table 1.

\section{RNA isolation, CDNA, qPCR and microarray}

RNA was isolated from abdominal aortas according to the manufacturer's instructions using the RNeasy fibrous tissue mini kit (QIAGEN - 74704). The isolated RNAs were used for cDNA synthesis according to the manufacturer's instructions using the RevertAid First Strand cDNA kit (Thermo Fisher Scientific - K1622). Quantitative polymerase chain reaction (qPCR) was performed using QuantStudio (Thermo Fisher Scientific) and SYBR Green qPCR Master Mix (Roche - 34226600). Primer sequences are available on request. Standard curves were used to correct for PCR efficiency. For microarray analysis, total RNA was sent to a commercial provider (ATLAS Biolabs $\mathrm{GmbH}$, Berlin, Germany) for further processing steps and final hybridization to an Affymetrix GeneChip Mouse Gene 2.0 ST Micro Array (Thermo Fisher Scientific), which was scanned with a GeneChip Scanner 3000 HR (Thermo Fisher Scientific). Raw data were background corrected and normalized by employing the RMA and median polish algorithms within the Affimetrix Transcriptome Analysis
Console 4.0.1 (Thermo Fisher Scientific) workflow. Gene expression was considered present when $\log _{2}$ expression $>5$, and considered changed between groups with a fold change $>|1.25|$. Differences in gene expression between treated and control animals were calculated by an empirical Bayes corrected ANOVA approach, and sorted by increasing $P$-value with the top candidates selected for qPCR validation. Subsequent gene set enrichment analysis of the differentially expressed genes was conducted using the online tool WebGestalt (Zhang et al. 2005) in combination with the Reactome database (Fabregat et al. 2016). For correlation studies, the gene expression values were directly correlated with the respective serum T3 or T4 levels using a rank-based Kendall correlation. The microarray data have been deposited with the NCBI GEO system under GSE119065.

\section{Results}

To define the non-genomic effects of $\mathrm{T} 3$ on aortic contractility, we pretreated isolated mouse aortas for $5 \mathrm{~min}$ with $0 \mathrm{nM}$ (hypothyroid condition), $1 \mathrm{nM}$ (euthyroid condition), 10 nM (mild hyperthyroid condition) and $100 \mathrm{nM}$ T3 (strong hyperthyroid condition). We then recorded the response to increasing concentrations of phenylephrine (PE) to quantify the contractile response to $\alpha 1$-adrenergic activation relative to the depolarizationinduced contraction by potassium chloride $(\mathrm{KCl})$. The studies revealed that although the $\mathrm{EC}_{50}$ values were similar between treated and control group, the maximal

Table 1 Antibodies used in the study to test phosphorylation of ERK, AKT and AMPK in aorta.

\begin{tabular}{|c|c|c|c|c|c|}
\hline Peptide/protein target & Name of the antibody & Manufacturer, catalog \# & $\begin{array}{l}\text { Species raised in; } \\
\text { monoclonal/polyclonal }\end{array}$ & Dilution used & RRID \\
\hline \multicolumn{6}{|l|}{ Primary antibodies } \\
\hline $\begin{array}{l}\text { Extracellular } \\
\text { signal-regulated kinase } \\
\text { (ERK) }\end{array}$ & $\begin{array}{l}\text { p44/42 MAPK (Erk1/2) } \\
\text { antibody }\end{array}$ & Cell Signalling - 9102 & Rabbit; polyclonal & $1: 1000$ & AB_330744 \\
\hline $\begin{array}{l}\text { Phosphorylated } \\
\text { extracellular signal- } \\
\text { regulated kinase (pERK) }\end{array}$ & $\begin{array}{l}\text { Phospho-p44/42 } \\
\text { MAPK (Erk1/2) }\end{array}$ & Cell Signalling - 9106 & Mouse; monoclonal & $1: 1000$ & AB_331768 \\
\hline Protein kinase $B(A K T)$ & Akt antibody & Cell Signalling - 9272 & Rabbit; polyclonal & $1: 1000$ & AB_329827 \\
\hline $\begin{array}{l}\text { Phosphorylated protein } \\
\text { kinase B (pAKT) }\end{array}$ & Phospho-Akt (Ser473) & Cell Signalling - 4060 & Rabbit; monoclonal & 1:1000 & AB_2315049 \\
\hline $\begin{array}{l}\text { 5'-AMPK activated protein } \\
\text { kinase }(\text { AMPK } \alpha 1)\end{array}$ & $\begin{array}{l}\text { Anti-AMPK } \alpha 1 \\
\text { antibody }\end{array}$ & Millipore - 07-350 & Rabbit; polyclonal & $1: 1000$ & AB_310542 \\
\hline Phosphorylated AMPK & $\begin{array}{r}\text { Phospho-AMPK } \alpha \\
(\text { Thr172) }(40 \mathrm{H} 9)\end{array}$ & Cell Signalling - 2535 & Rabbit; monoclonal & $1: 1000$ & AB_331250 \\
\hline \multicolumn{6}{|l|}{ Secondary antibodies } \\
\hline & $\begin{array}{l}\text { Rabbit } \\
\text { immunoglobulins }\end{array}$ & Dako - P0448 & Goat; polyclonal & $1: 5000$ & AB_2617138 \\
\hline & $\begin{array}{l}\text { Mouse } \\
\text { immunoglobulins }\end{array}$ & Dako - P0260 & Rabbit; polyclonal & $1: 5000$ & AB_2636929 \\
\hline
\end{tabular}


contraction at high doses of PE was strongly reduced in hypo- and hyperthyroid conditions (Fig. 1A, B, C and Table 2; please note that the euthyroid control group is included in all three figures for direct comparison; $\mathrm{A}: \mathrm{EC}_{50}$ $P=0.36$; bottom $P=0.23$, top $P=<0.0001$; $\mathrm{B} \mathrm{EC}_{50} P=0.85$; bottom $P=0.50$; top $P<0.0001$; C: $\mathrm{EC}_{50} P=0.26$; bottom $P=0.55$; top $P=0.0002$ ). No alterations were observed after prestimulation with $100 \mathrm{nM}$ reverse $\mathrm{T} 3$, suggesting that the effect is specific for T3 (data not shown). We then tested for a possible activation of the intracellular signalling pathways ERK, AKT or AMPK using Western blot with phosphorylation-specific antibodies. The incubation of isolated aortic rings with $100 \mathrm{nM}$ T3 or rT3 for $10 \mathrm{~min}$, however, showed no changes in AKT, ERK or AMPK phosphorylation in any condition (Fig. 1D). Likewise, no alteration was observed after $120 \mathrm{~min}$ (data not shown).

To test for genomic effects of TH on aortic function, we treated mice for 4 days with $\mathrm{T} 4$ in drinking water. The treatment resulted in a 3-fold increase in serum total T4, while serum total T3 was 2.2-fold elevated (Fig. 2A). When we then tested the aortic response of these animals to PE in the wire myograph, we observed a significantly increased contractility at high levels of PE (Fig. $2 \mathrm{~B}$ and Table 2; $\mathrm{EC}_{50} P=0.26$; bottom $P=0.12$; top $P=0.0012$ ). Next, we tested mice devoid of TH receptor $\beta$ (Forrest et al. 1996a) as a model of endogenous hyperthyroidism for the aortic response to PE (Fig. 1C and Table 2). Surprisingly, although we observed a higher contraction at low levels of PE and normal $\mathrm{EC}_{50}$ in these animals, the maximum contraction was not altered despite the hyperthyroidism of the mice ( $\mathrm{EC}_{50} P=0.18$; bottom $P=0.04$; top $P=0.7$ ). This suggests that TH receptor $\beta$ is required for the elevated maximum contraction at high PE levels observed in hyperthyroid animals. We also did not observe any changes in AKT, ERK or AMPK phosphorylation in the TR $\beta$ knockout mice (Fig. 2D), indicating no permanent alterations of these non-genomic pathways by the lack of TR $\beta$.
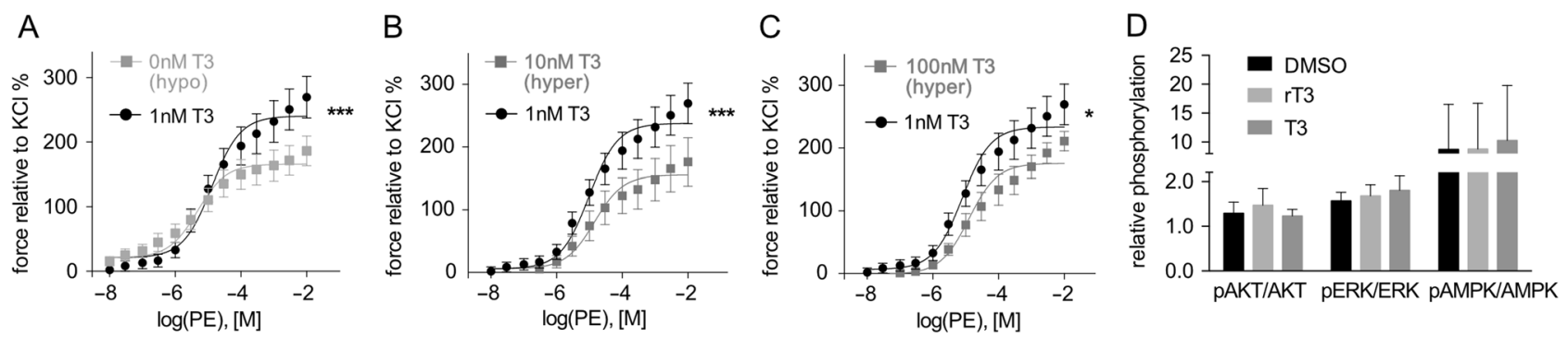

\section{Figure 1}

Aortic response ex vivo recorded in a wire myograph to phenylephrine (PE) after 5 min prestimulation with solvent (0 nM T3), 1 nM T3 (A), 10 nM T3 (B) or $100 \mathrm{nM}$ T3 (C). Please note that the $1 \mathrm{nM}$ T3 curve serves as euthyroid reference control and is thus included for better comparison in (A, $B$ and C). All values are mean \pm S.E.M. of $n=8$. ***P<0.001 for top of curve. (D) Phosphorylation of ERK, AKT and AMPK after prestimulation of aortic rings for 10 min with DMSO, $100 \mathrm{nM}$ T3 or $100 \mathrm{nM}$ rT3 as assessed by Western blot. All values are mean \pm S.E.M. of $n=9-10$. 
Table $2 \mathrm{EC}_{50}$, bottom and top values according to non-linear fit model.

\begin{tabular}{|c|c|c|c|}
\hline Condition & $E_{50}(M)$ & Bottom $(\% \mathrm{KCl})$ & Top $(\% \mathrm{KCl})$ \\
\hline 0 nM T3 & $6.0 \times 10^{-6}$ & 28.91 & 167.1 \\
\hline 1 nM T3 & $1.1 \times 10^{-5}$ & 11.33 & 238.7 \\
\hline 10 nM T3 & $1.2 \times 10^{-5}$ & 0.73 & 154.7 \\
\hline 100 nM T3 & $2.0 \times 10^{-5}$ & 3.55 & 182.3 \\
\hline WT untreated & $5.14 \times 10^{-6}$ & 20.87 & 212.9 \\
\hline WT T4 4 days & $2.55 \times 10^{-6}$ & 49.01 & 261.1 \\
\hline TR $\beta$ control & $5.24 \times 10^{-6}$ & 14.44 & 375.7 \\
\hline TR $\beta$ knockout & $2.39 \times 10^{-6}$ & 73.71 & 367.1 \\
\hline
\end{tabular}

contributions remain unclear. In this study, we used an ex vivo wire myograph model to dissect the short-term (i.e. a time frame of non-genomic actions) and long-term (i.e. a time frame of genomic actions) effects of TH on the abdominal aorta in mice.

\section{Non-genomic vs genomic effects}

To test the non-genomic effects, T3 was applied to the aorta for $5 \mathrm{~min}$ before starting a PE dose-response curve. This time frame is sufficient to trigger the non-genomic effects (Cao et al. 2005, Hiroi et al. 2006), but too short to mediate any genomic actions, which are in the range of hours. Our results show that too low as well as too high levels of T3 cause vasodilation, but only in the presence of a strong contractile stimulus. This concurs with previous studies (Pantos et al. 2001), and suggests that nongenomic signalling might only be relevant in vivo under highly pathological conditions, where the sympathetic input to the aorta is supraphysiologically elevated. More importantly, when we treated mice for 4 days with T4, the genomic effects of the hormone on contractility where opposite to the non-genomic actions, that is increased vasoconstriction at high PE levels, suggesting that genomic actions prevail in an endocrinologically more relevant time frame. Although other studies showed reduced contractile response in rat aortas treated with TH (McAllister et al. 1998, Pantos et al. 2001, CarrilloSepulveda et al. 2013), our study is the first to use mouse aorta and a milder paradigm of hyperthyroidism with approx. $200 \mu \mathrm{g} / \mathrm{kg}$ T4 per day for 4 days as compared to 2 weeks of $70 \mu \mathrm{g} / \mathrm{kg}$ T3 (Carrillo-Sepulveda et al. 2013), 6-12 weeks of $300 \mu \mathrm{g} / \mathrm{kg}$ T3 (McAllister et al. 1998) or 3 days of $500 \mathrm{mg} / \mathrm{kg}$ T4 (Honda et al. 2000). The findings of improved contractility also concur with previous studies showing increased constriction in mesenteric arteries of mice treated for 14 days with $\mathrm{T} 3$ and reduced tail artery constriction in a mouse model of TR $\alpha 1$-mediated hypothyroidism (Warner et al. 2013). Likewise, aortas of hypothyroid rats also displayed reduced sensitivity to PE (Sabio et al. 1994, Grieve et al. 1999, Pantos et al. 2006).

Classically it is assumed that the rapid non-genomic effects of T3 are mediated by the PI3 kinase pathway, leading to phosphorylation of AKT and subsequent activation of nitric oxide synthase (Hiroi et al. 2006, Carrillo-Sepulveda et al. 2010), which reduces vasomotor tone (Luo et al. 2000). We did however not observe any alterations in AKT, ERK or AMPK phosphorylation in the 10 min time frame of our experiment. This could be caused by the fact that AKT phosphorylation occurs only transiently and may have been missed in our paradigm, although the first non-genomic T3 effects on AKT were noticed after $5 \mathrm{~min}$ in human fibroblasts (Cao et al. 2005) and rat pituitary cells (Martin et al. 2014) as well as on nitric oxide synthase activity after $10 \mathrm{~min}$ (Hiroi et al. 2006).
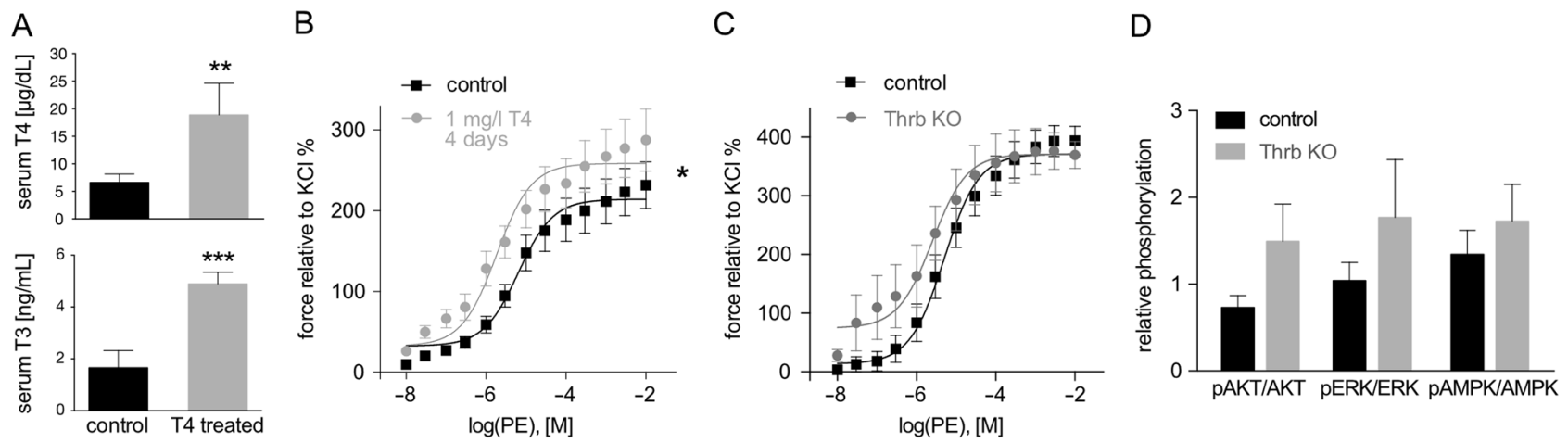

Figure 2

(A) Serum total T4 and T3 levels after 4 day treatment with $1 \mathrm{mg} / \mathrm{L} \mathrm{T4}$ in drinking water. Values are mean \pm S.E.M. of $n=6$. $* \star P<0.01$; $* \star * P<0.001$ with unpaired 2-tailed $t$ test. (B) Aortic response ex vivo recorded in a wire myograph to phenylephrine (PE) in mice treated for 4 days with $1 \mathrm{mg} / \mathrm{L} \mathrm{T4}$ in drinking water as compared to controls. Values are mean \pm S.E.M. of $n=10 * P<0.05$ for top of curve. (C) Aortic response ex vivo recorded in a wire myograph to phenylephrine (PE) in mice lacking TR $\beta$ as compared to controls. Values are mean \pm s.E.M. of $n=5$. $* P<0.05$ for bottom of curve. (D) Phosphorylation of ERK, AKT and AMPK of aortic rings from wild type or TR $\beta$ knockout mice as assessed by Western blot. All values are mean \pm S.E.M. of $n=4$. 
A

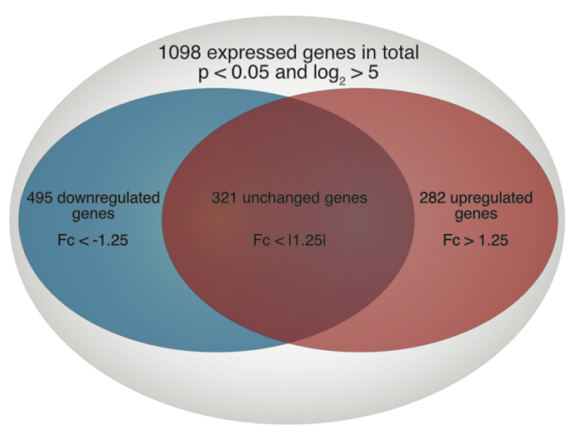

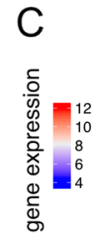

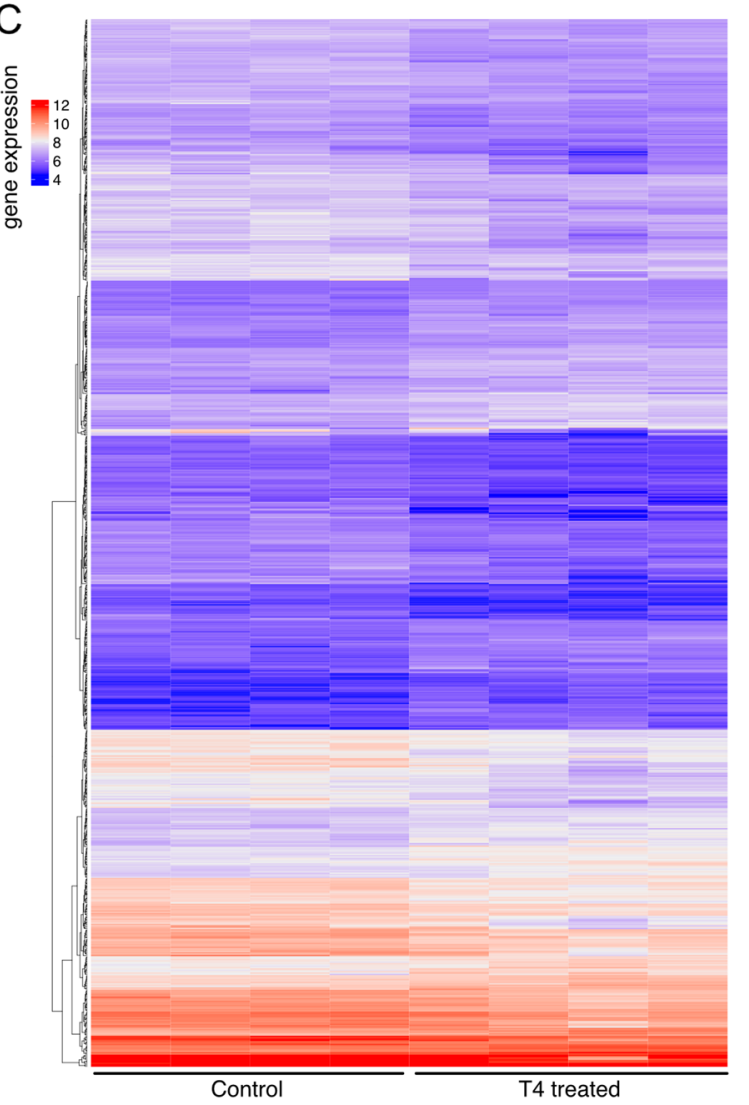

B

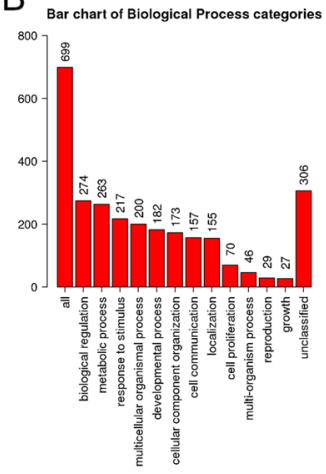

D

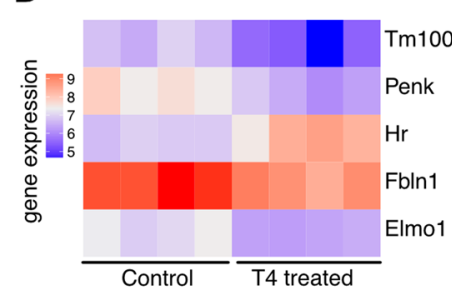

F

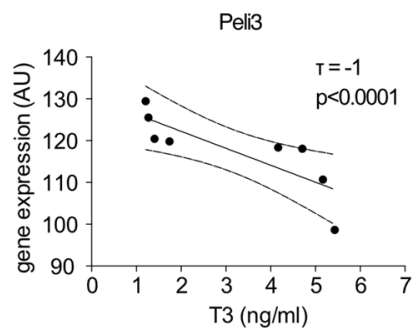

Pola1

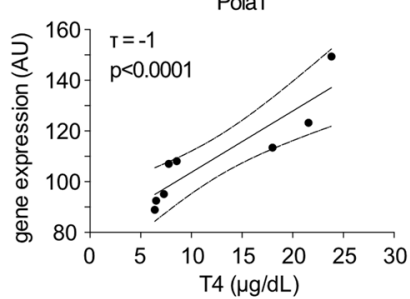

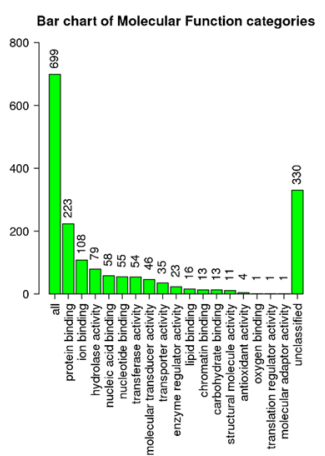

E

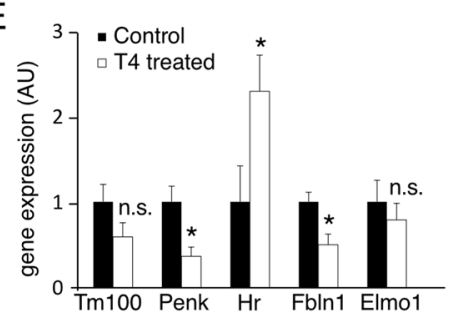

Maf

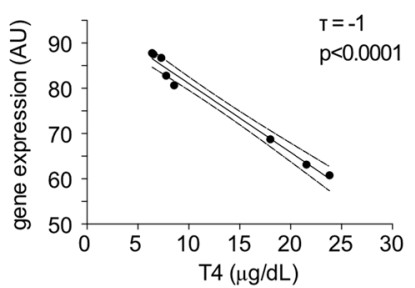

Msantd2

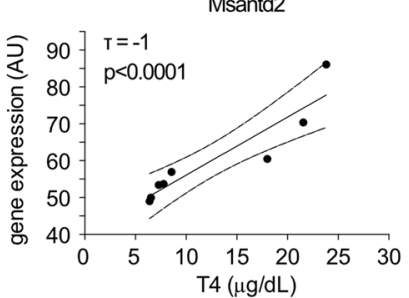

\section{Figure 3}

(A) Overview of the genomic effects of T4 on aortic gene expression in mice treated for 4 days with $1 \mathrm{mg} / \mathrm{L}$ T4 in drinking water as compared to controls as studied by micoarray analysis. (B) Weighted gene set enrichment analysis of the microarray results. The numbers on the bars indicate the number of genes found to be significantly changed in the respective pathway. (C) Unbiased hierarchical clustering of the microarray results with the top five candidate genes by $P$-value in (D), which were validated using qPCR in a different cohort (E). Values are mean \pm S.E.M. of $n=4-5$. * $P<0.05$ with unpaired 2-tailed $t$ test. (F) Correlation of gene expression as assessed by microarray with the individual total T3 and T4 levels of the respective animals of the top correlated genes with $P<0.0001$. Tm100, transmembrane protein 100; Penk, preproenkephaline; Hr, hairless; Fbln1, fibulin 1; Elmo1, engulfment and cell motility 1; Pel3, HXXXD-type acyltransferase family protein; Maf, MAF bZIP transcription factor; Pola1, DNA Polymerase Alpha 1; Msantd2, Myb/SANT DNA Binding Domain Containing 2.

As AKT phosphorylation upon T3 stimulation declined again already after $15 \mathrm{~min}$ (Martin et al. 2014), it can be assumed that the non-genomic effects are very transient even under continued T3 exposure, thus questioning their biological relevance in vivo, where TH levels usually do not change abruptly within minutes.
To study the biological relevance of non-genomic actions in a longer time frame, different animal models were made recently, providing some interesting genetic support for non-genomic actions in vivo (Martin et al. 2014, Hönes et al. 2017). However, it needs to be kept in mind that mutations in the DNA-binding domain of TRs 
can also produce unexpected gain-of-function effects, that is binding to DNA motifs that are not bound by a wildtype receptor. Together with the additional compensatory adaptations that can occur in genetic models, this prevents a straightforward interpretation of the mutant TR mouse phenotypes in support of non-genomic actions in vivo.

\section{Role of TH receptor $\beta$}

Most interestingly, when we tested aortic contractility in mice lacking TR $\beta$, which have endogenously elevated T3 (2.5-fold) and T4 (3-fold) levels (Forrest et al. 1996b), we observed higher vasoconstriction, but no hypersensitivity to PE. As the T3 and T4 levels are roughly comparable to our $\mathrm{T} 4$ treatment paradigm, the findings could indicate a previously unknown role for TR $\beta$ in aortic vasoconstriction. However, it needs to be kept in mind that TR $\beta$ knockout mice are hyperthyroid during their entire life, allowing for long-term adaptations that might not occur after only four days of treatment. In addition, the 1-h relaxation time in the myography chamber might reduce the available intracellular T3 and T4 concentrations, which would affect the hyperthyroid conditions more than the euthyroid conditions and could obscure subtle effects. Nevertheless, impaired relaxation has been observed previously in mice expressing a mutant TR $\beta$ (Owen et al. 2007), and blocking TR $\beta$ in mesenteric arteries inhibited the T3-induced nongenomic vasodilation (Zloh et al. 2016). Taken together, these findings suggest that activation of TR $\beta$ might be beneficial for aortic stiffness, a notion that is supported by reports that the TR $\beta$-selective agonist GC- 1 delays the onset of atherosclerosis in ApoE-deficient mice (Kannisto et al. 2014). Interestingly, however, the transporter SLC10A1, which seems to be required for GC-1 uptake (Kersseboom et al. 2017), was below the expression level threshold in our microarray study.

\section{Possible mechanisms of long-term TH action}

Previous studies suggested that alterations in adrenergic signalling might contribute to explain the effects of $\mathrm{TH}$ on vascular function (Pappas et al. 2009). Our study now adds a number of other possible TH targets in the regulatory unit of the aorta, including the endothelium, that could be partially involved in explaining the functional changes. Most remarkably, one of the top candidates of genomic TH action in the aorta was Hairless, a gene well known to be regulated by TH for instance in brain and simultaneously a corepressor for TH signalling (Thompson \& Bottcher 1997, Mayerl et al. 2014).
Another target gene was Fibulin1, which is important for the extracellular matrix (Argraves et al. 2003) and was downregulated by $\mathrm{TH}$, concurring with previous studies in the heart (Miller et al. 2004). Given the importance of the extracellular matrix for blood vessel function (Eble \& Niland 2009), this TH target gene might well contribute to explain the functional alterations. A possibly relevant target gene is also Penk (pre-proenkephalin), an endogenous opioid peptide (Konig et al. 1996). As opioid receptors contribute to the release of $\mathrm{NO}$ and vasodilation (Champion et al. 2002), it could be speculated that reduced expression of Penk leads to reduced autocrine action and impaired vasodilation, which was indeed observed in our myography studies of T4 treated mice. Other genes identified by direct correlation of expression and serum T3 or T4 concentrations such as Peli3, Maf, Pola1 and Msantd2 do not have a known connection to aortic function, but may serve as transcriptional markers of aortic TH action.

\section{Conclusions}

Taken together, our findings show that $\mathrm{TH}$ affects aortic contractility by genomic and non-genomic actions. However, the biological relevance of non-genomic actions seems very limited: First, the functional impairments in vasoconstriction occur only at pathological conditions when altered $\mathrm{TH}$ levels converge with extremely high adrenergic stimulation, which could potentially be reached that is in patients with pheochromocytomas (Kantorovich \& Pacak 2010). Secondly, non-genomic and genomic actions lead to opposite functional phenotypes, suggesting that when TH levels are changed for more than a few hours, the genomic actions become predominant. Thirdly, the proposed phosphorylation of AKT seems to be very transient even under continued exposure to $\mathrm{TH}$, and was not observed in the time frame of our experiment, thus questioning its biological relevance for conditions where TH levels are changed over a longer period of time. In contrast to the non-genomic actions, the genomic actions of TH caused significant changes in aortic gene expression in vivo. Here, several novel target genes have been identified, which could pave the way for further studies to unravel how $\mathrm{TH}$ affects aortic contractility and stiffness, or could constitute novel biomarkers for TH action in the vascular system.

\section{Declaration of interest}

The authors declare that there is no conflict of interest that could be perceived as prejudicing the impartiality of the research reported. 


\section{Funding}

We are grateful for the support offered by the members of the GTH by way of animal caretaking. This work was supported by the Deutsche Forschungsgemeinschaft (Heisenberg Programm MI1242/2-2 and 3-2, SPP1629 Thyroid TransAct MI1242/5-1, and the GRK1957 Adipocyte-BrainCrosstalk).

\section{References}

Argraves WS, Greene LM, Cooley MA \& Gallagher WM 2003 Fibulins: physiological and disease perspectives. EMBO Reports 4 1127-1131. (https://doi.org/10.1038/sj.embor.7400033)

Cao X, Kambe F, Moeller LC, Refetoff S \& Seo H 2005 Thyroid hormone induces rapid activation of Akt/protein kinase B-mammalian target of rapamycin-p70s6K cascade through phosphatidylinositol 3-kinase in human fibroblasts. Molecular Endocrinology 19 102-112. (https:// doi.org/10.1210/me.2004-0093)

Carrillo-Sepulveda MA, Ceravolo GS, Fortes ZB, Carvalho MH, Tostes RC, Laurindo FR, Webb RC \& Barreto-Chaves MLM 2010 Thyroid hormone stimulates NO production via activation of the PI3K/Akt pathway in vascular myocytes. Cardiovascular Research 85 560-570. (https://doi.org/10.1093/cvr/cvp304)

Carrillo-Sepulveda MA, Ceravolo GS, Furstenau CR, Monteiro Pde Pde S, Bruno-Fortes Z, Carvalho MH, Laurindo FR, Tostes RC, Webb RC \& Barreto-Chaves ML 2013 Emerging role of angiotensin type 2 receptor (AT2R)/Akt/NO pathway in vascular smooth muscle cell in the hyperthyroidism. PLoS ONE 8 e61982. (https://doi.org/10.1371/ journal.pone.0061982)

Champion HC, Bivalacqua TJ, Zadina JE, Kastin AJ, Hyman AL \& Kadowitz PJ 2002 Role of nitric oxide in mediating vasodilator responses to opioid peptides in the rat. Clinical and Experimental Pharmacology and Physiology 29 229-232. (https://doi. org/10.1046/j.1440-1681.2002.03634.x)

Delitala AP, Orru M, Filigheddu F, Pilia MG, Delitala G, Ganau A, Saba PS, Decandia F, Scuteri A, Marongiu M, et al. 2015 Serum free thyroxine levels are positively associated with arterial stiffness in the SardiNIA study. Clinical Endocrinology 82 592-597. (https://doi. org/10.1111/cen.12532)

Dillmann W 2010 Cardiac hypertrophy and thyroid hormone signaling. Heart Failure Reviews 15 125-132. (https://doi.org/10.1007/s10741008-9125-7)

Eble JA \& Niland S 2009 The extracellular matrix of blood vessels. Current Pharmaceutical Design 15 1385-1400. (https://doi. org/10.2174/138161209787846757)

Fabregat A, Sidiropoulos K, Garapati P, Gillespie M, Hausmann K, Haw R, Jassal B, Jupe S, Korninger F, McKay S, et al. 2016 The reactome pathway knowledge base. Nucleic Acids Research $\mathbf{4 4}$ D481-D487. (https://doi.org/10.1093/nar/gkv1351)

Flamant F, Cheng SY, Hollenberg AN, Moeller LC, Samarut J, Wondisford FE, Yen PM \& Refetoff S 2017 Thyroid hormone signaling pathways: time for a more precise nomenclature. Endocrinology 158 2052-2057. (https://doi.org/10.1210/en.201700250)

Forrest D, Erway LC, Ng L, Altschuler R \& Curran T 1996a Thyroid hormone receptor beta is essential for development of auditory function. Nature Genetics 13 354-357. (https://doi.org/10.1038/ ng0796-354)

Forrest D, Hanebuth E, Smeyne RJ, Everds N, Stewart CL, Wehner JM \& Curran T $1996 b$ Recessive resistance to thyroid hormone in mice lacking thyroid hormone receptor beta: evidence for tissue-specific modulation of receptor function. EMBO Journal 15 3006-3015. (https://doi.org/10.1002/j.1460-2075.1996.tb00664.x)

Gachkar S, Oelkrug R, Martinez-Sanchez N, Rial-Pensado E, Warner A, Hoefig CS, Lopez M \& Mittag J 2017 3-Iodothyronamine induces tail vasodilation Through central action in male mice. Endocrinology 158 1977-1984. (https://doi.org/10.1210/en.2016-1951)

Grieve DJ, Fletcher S, Pitsillides AA, Botham KM \& Elliott J 1999 Effects of oral propylthiouracil treatment on nitric oxide production in rat aorta. British Journal of Pharmacology 127 1-8. (https://doi. org/10.1038/sj.bjp.0702501)

Hiroi Y, Kim HH, Ying H, Furuya F, Huang Z, Simoncini T, Noma K, Ueki K, Nguyen NH, Scanlan TS, et al. 2006 Rapid nongenomic actions of thyroid hormone. PNAS 103 14104-14109. (https://doi. org/10.1073/pnas.0601600103)

Honda H, Iwata T, Mochizuki T \& Kogo H 2000 Changes in vascular reactivity induced by acute hyperthyroidism in isolated rat aortae. General Pharmacology 34 429-434. (https://doi.org/10.1016/S03063623(01)00080-5)

Hönes GS, Rakov H, Logan J, Liao XH, Werbenko E, Pollard AS, Præstholm SM, Siersbæk MS, Rijntjes E, Gassen J, et al. 2017 Noncanonical thyroid hormone signaling mediates cardiometabolic effects in vivo. PNAS 114 E11323-E11332. (https://doi.org/10.1073/ pnas.1706801115)

Ittermann T, Lorbeer R, Dorr M, Schneider T, Quadrat A, Hesselbarth L, Wenzel M, Lehmphul I, Kohrle J, Mensel B, et al. 2016 High levels of thyroid-stimulating hormone are associated with aortic wall thickness in the general population. European Radiology 26 4490-4496. (https://doi.org/10.1007/s00330-016-4316-4)

Kalyanaraman H, Schwappacher R, Joshua J, Zhuang S, Scott BT, Klos M, Casteel DE, Frangos JA, Dillmann W, Boss GR, et al. 2014 Nongenomic thyroid hormone signaling occurs through a plasma membrane-localized receptor. Science Signaling 7 ra48. (https://doi. org/10.1126/scisignal.2004911)

Kannisto K, Rehnmark S, Slatis K, Webb P, Larsson L, Gafvels M, Eggertsen G \& Parini P 2014 The thyroid receptor beta modulator GC-1 reduces atherosclerosis in ApoE deficient mice. Atherosclerosis 237 544-554. (https://doi.org/10.1016/j.atherosclerosis.2014.09.035)

Kantorovich V \& Pacak K 2010 Pheochromocytoma and paraganglioma. Progress in Brain Research 182 343-373. (https://doi.org/10.1016/ S0079-6123(10)82015-1)

Kersseboom S, van Gucht ALM, van Mullem A, Brigante G, Farina S, Carlsson B, Donkers JM, van de Graaf SFJ, Peeters RP \& Visser TJ 2017 Role of the bile acid transporter SLC10A1 in liver targeting of the lipid-lowering thyroid hormone analog eprotirome. Endocrinology 158 3307-3318. (https://doi.org/10.1210/en.2017-00433)

Klein I \& Ojamaa K 2001 Thyroid hormone and the cardiovascular system. New England Journal of Medicine 344 501-509. (https://doi. org/10.1056/NEJM200102153440707)

Konig M, Zimmer AM, Steiner H, Holmes PV, Crawley JN, Brownstein MJ \& Zimmer A 1996 Pain responses, anxiety and aggression in mice deficient in pre-proenkephalin. Nature $\mathbf{3 8 3}$ 535-538. (https://doi.org/10.1038/383535a0)

Luo Z, Fujio Y, Kureishi Y, Rudic RD, Daumerie G, Fulton D, Sessa WC \& Walsh K 2000 Acute modulation of endothelial Akt/PKB activity alters nitric oxide-dependent vasomotor activity in vivo. Journal of Clinical Investigation 106 493-499. (https://doi.org/10.1172/JCI9419)

Martin NP, Marron Fernandez de Velasco E, Mizuno F, Scappini EL, Gloss B, Erxleben C, Williams JG, Stapleton HM, Gentile S \& Armstrong DL 2014 A rapid cytoplasmic mechanism for PI3 kinase regulation by the nuclear thyroid hormone receptor, TRbeta, and genetic evidence for its role in the maturation of mouse hippocampal synapses in vivo. Endocrinology 155 3713-3724. (https://doi.org/ 10.1210/en.2013-2058)

Mayerl S, Muller J, Bauer R, Richert S, Kassmann CM, Darras VM, Buder K, Boelen A, Visser TJ \& Heuer H 2014 Transporters MCT8 and OATP1C1 maintain murine brain thyroid hormone homeostasis. Journal of Clinical Investigation 124 1987-1999. (https://doi. org/10.1172/JCI70324)

McAllister RM, Grossenburg VD, Delp MD \& Laughlin MH 1998 Effects of hyperthyroidism on vascular contractile and relaxation responses. 
American Journal of Physiology 274 E946-E953. (https://doi. org/10.1152/ajpendo.1998.274.5.E946)

Miller LD, McPhie P, Suzuki H, Kato Y, Liu ET \& Cheng SY 2004 Multitissue gene-expression analysis in a mouse model of thyroid hormone resistance. Genome Biology 5 R31. (https://doi.org/10.1186/ gb-2004-5-5-r31)

Moulakakis KG, Sokolis DP, Perrea DN, Dosios T, Dontas I, Poulakou MV, Dimitriou CA, Sandris G \& Karayannacos PE 2007 The mechanical performance and histomorphological structure of the descending aorta in hyperthyroidism. Angiology 58 343-352. (https://doi. org/10.1177/0003319707301759)

Obuobie K, Smith J, Evans LM, John R, Davies JS \& Lazarus JH 2002 Increased central arterial stiffness in hypothyroidism. Journal of Clinical Endocrinology and Metabolism 87 4662-4666. (https://doi. org/10.1210/jc.2002-020493)

Owen PJ, Ying H, Lang D, Tomlinson D, Lewis MJ, Cheng SY \& Lazarus JH 2007 Endothelial dysfunction in a murine model of thyroid hormone resistance. European Journal of Clinical Investigation 37 390-395. (https://doi.org/10.1111/ j.1365-2362.2007.01799.x)

Pantos CI, Tzilalis V, Giannakakis S, Cokkinos DD, Tzeis SM, Malliopoulou V, Mourouzis I, Asimakopoulos P, Carageorgiou H, Varonos DD, et al. 2001 Phenylephrine induced aortic vasoconstriction is attenuated in hyperthyroid rats. International Angiology 20 181-186.

Pantos C, Mourouzis C, Katramadou M, Saranteas T, Mourouzis I, Karageorgiou H, Tesseromatis C, Kostopanagiotou G, Asimacopoulos P \& Cokkinos DV 2006 Decreased vascular reactivity to alpha1 adrenergic stimulation in the presence of hypothyroid state: a part of an adaptive response? International Angiology $\mathbf{2 5}$ 216-220.

Pappas M, Mourouzis K, Karageorgiou H, Tesseromatis C, Mourouzis I, Kostopanagiotou G, Pantos C \& Cokkinos DV 2009 Thyroid hormone modulates the responsiveness of rat aorta to alpha1adrenergic stimulation: an effect due to increased activation of beta2-adrenergic signaling. International Angiology 28 474-478.

Sabio JM, Rodriguez-Maresca M, Luna JD, Garcia del Rio C \& Vargas F 1994 Vascular reactivity to vasoconstrictors in aorta and renal vasculature of hyperthyroid and hypothyroid rats. Pharmacology 49 257-264. (https://doi.org/10.1159/000139241)

Thompson CC \& Bottcher MC 1997 The product of a thyroid hormoneresponsive gene interacts with thyroid hormone receptors. PNAS $\mathbf{9 4}$ 8527-8532. (https://doi.org/10.1073/pnas.94.16.8527)

Warner A, Rahman A, Solsjö P, Gottschling K, Davis B, Vennstrom B, Arner A \& Mittag J 2013 Inappropriate heat dissipation ignites brown fat thermogenesis in mice with a mutant thyroid hormone receptor alpha 1. PNAS 110 16241-16246. (https://doi.org/10.1073/ pnas.1310300110)

Yen PM 2001 Physiological and molecular basis of thyroid hormone action. Physiological Reviews 81 1097-1142. (https://doi.org/10.1152/ physrev.2001.81.3.1097)

Zhang B, Kirov S \& Snoddy J 2005 WebGestalt: an integrated system for exploring gene sets in various biological contexts. Nucleic Acids Research 33 W741-W748. (https://doi.org/10.1093/nar/gki475)

Zloh M, Perez-Diaz N, Tang L, Patel P \& Mackenzie LS 2016 Evidence that diclofenac and celecoxib are thyroid hormone receptor beta antagonists. Life Sciences 146 66-72. (https://doi.org/10.1016/j. lfs.2016.01.013)

Received in final form 6 December 2018

Accepted 3 January 2019

Accepted Preprint published online 3 January 2019
(C) 2019 Society for Endocrinology Published by Bioscientifica Ltd. Printed in Great Britain 